\title{
A Natural Tetrahydropyrimidine Protects Small Bowel from Cold Ischemia and Subsequent Warm in vitro Reperfusion Injury
}

\author{
Lai Wei $^{\mathrm{a}} \quad$ Annika Wedeking ${ }^{\mathrm{b}}$ Reinhard Büttner ${ }^{c}$ Jörg C. Kalff ${ }^{\mathrm{d}}$ \\ René H. Tolba ${ }^{a}$ e Gerhild van Echten-Deckert ${ }^{b}$ \\ ${ }^{a}$ House of Experimental Therapy, ${ }^{b}$ Kekulé-Institute LIMES Membrane Biology and Lipid Biochemistry, ${ }^{\mathrm{C}}$ Institute of \\ Pathology, and ${ }^{\mathrm{d}}$ Department of Surgery, University of Bonn, Bonn, ${ }^{\mathrm{e}}$ Institute of Laboratory Animal Science, \\ University Hospital Aachen, Aachen, Germany
}

\section{Key Words}

Small bowel transplantation $\cdot$ Ceramide $\cdot$ Cold storage • Ectoine $\cdot$ Ischemia/reperfusion injury $\cdot$ Polysol $\cdot$

Tetrahydropyrimidine

\begin{abstract}
Objective: Ischemia/reperfusion (I/R) injury is a major difficulty in small bowel transplantation. Many postoperative complications are caused by damage to the intestinal mucosa following organ retrieval and during cold storage. Here we investigate whether 1-, 4-, 5-, 6-tetrahydro-2-methyl-4pyrimidine carboxylic acid (THP) can protect ileal mucosa and muscularis against cold ischemia and subsequent warm in vitro reperfusion injury. Methods: Small rat bowels were stored in the absence or presence of THP or its synthetic derivative lauryl-THP for $18 \mathrm{~h}$ at $4^{\circ} \mathrm{C}$. Several biochemical parameters were evaluated following isolated reperfusion in tissue grafts and/or effluent solution. Graft morphology was analyzed by electron microscopy. Ceramide was quantified as a potential target of THP action. Results: THP considerably inhibited apoptosis and improved all parameters illustrating membrane and subcellular integrity and functionality. Parallel studies with lauryl-THP failed to show a similar protective effect. Lauryl-THP, in contrast to THP, also failed to decrease tissue ceramide content, indicating the involvement of this well-known mediator of cellular stress response.
\end{abstract}

Conclusions: THP effectively protects ileal mucosa and muscularis against ischemia and reperfusion injury, indicating for the first time the clinical relevance of this new and promising molecule that might become a central component in tissue and organ protection in the near future.

Copyright $\odot 2009$ S. Karger AG, Base

\section{Introduction}

Small bowel transplantation has been proposed as treatment for patients with intestinal failure or with lifethreatening complications of total parenteral nutrition (e.g. related liver disease, catheter infections). However, patient outcome after small bowel transplantation still remains inferior in comparison to other solid organ transplantations, such as those for kidney or liver [1]. Although development of new immunosuppressive drugs and surgical techniques improved the results of small bowel transplantation, ischemia and subsequent reperfusion injury remains a major obstacle to successful small bowel transplantation [2]. Ischemia/reperfusion (I/R) in-

R.H. Tolba and G. van Echten-Deckert contributed equally to this paper.

\section{KARGER \\ Fax +4161306 1234 \\ E-Mail karger@karger.ch}

www.karger.com (c) 2009 S. Karger AG, Basel

$1015-2008 / 09 / 0764-0212 \$ 26.00 / 0$

Accessible online at:

www.karger.com/pat
Gerhild van Echten-Deckert

Kekulé-Institute of Organic Chemistry and Biochemistry

Gerhard-Domagk-Strasse 1

DE-53121 Bonn (Germany)

Tel. +49 228732 703, Fax +49228 737 778, E-Mail g.echten.deckert@uni-bonn.de 
jury causes tissue damage [3, 4], enhances graft immunogenicity, increases acute and/or chronic rejection, and consequently reduces long-term graft survival [5]. It is therefore of primary interest to reduce I/R injury and to optimize organ preservation, thus improving the clinical outcome of small bowel transplantation. The current clinical standard for small bowel preservation is cold static storage using University of Wisconsin solution (UW). Despite its overall acceptance as the first choice for solid organs, UW is not able to effectively preserve small bowel grafts $[6,7]$. The outcome of small bowel transplantation using UW is quite limited since the storage time is restricted to only $6-8 \mathrm{~h}$, coupled with an overall 1-year graft survival of 65\% [8]. Compared to UW, Polysol showed a superior potential for small bowel preservation [9].

The compatible solute 1-, 4-, 5-, 6-tetrahydro-2-methyl-4-pyrimidine carboxylic acid (THP, also named ectoine; fig. 1) is produced by Halorhodospira halochloris and other aerobic chemoheterotrophic bacteria and protects these microorganisms against environmental stress including dryness and high salinity, thus allowing them to survive under extreme conditions [10]. As indicated by its name, a compatible solute is a water-soluble organic molecule of low molecular weight, which is compatible with the metabolism of the microorganism by which it is produced [11]. Interestingly, THP has also been shown to protect mammalian cells from environmental stress [12, 13]. This protective effect was accompanied by a decrease in cellular levels of ceramide [13], a well-known mediator of the cellular stress response [14]. Furthermore, we have shown that 2 ceramide-derived sphingolipids are involved in postsurgical inflammation of the intestinal muscularis layer [15]. Collectively, these findings led to the assumption that THP might be a helpful addendum to organ preservation solutions. To verify our hypothesis, we assessed whether THP is able to reduce injury caused during cold ischemia and subsequent warm in vitro reperfusion and to maintain the structural integrity and function of the small bowel during organ preservation. The data of the present study demonstrate that THP indeed convincingly prevents tissue damage following ischemia. This protective effect is accompanied by a reduction of ceramide in intestinal tissue. On the other hand, lauryl-THP (fig. 1), a synthetic derivative of THP, assumed to be inserted into cellular plasma membranes, was incapable of overcoming tissue injury and did not affect the content of ceramide.

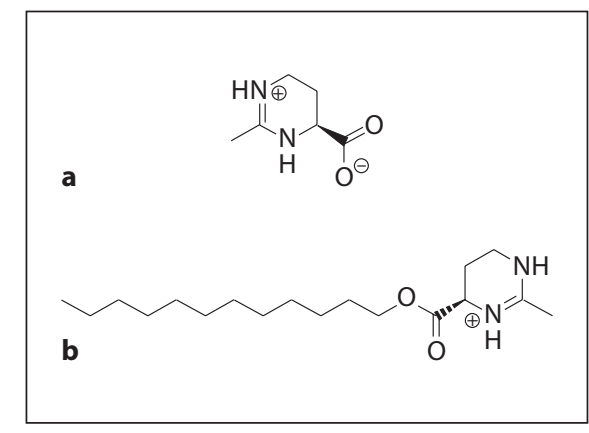

Fig. 1. Structure of THP (1-, 4-, 5-, 6-tetrahydro-2-methyl-4-pyrimidine carboxylic acid; a) and of lauryl-THP (b).

\section{Materials and Methods}

All animal experiments were performed in accordance with German federal laws regarding the protection of animals. This study also complied with institution guidelines as well as the criteria in the 'Guide for the Care and Use of Laboratory Animals' (NIH publication 86-23, revised 1985). Male Wistar rats weighing between 250 and $300 \mathrm{~g}$ were used as donors, and randomly assigned to 1 of 3 groups ( $n=6$ each): a Polysol group (group P); a Polysol + THP group (group THP), and a Polysol + lauryl-THP (group L-THP). Polysol was sourced from Doorzand Medical Innovations, Amsterdam, The Netherlands, and its ingredients are given in table 1. THP was from Merck, Darmstadt, Germany. Lauryl-THP was synthesized as described by Wedeking [13]. Animals were fed a rodent standard diet (SSniff Products, Soest, Germany) and had free access to sterile water. All animals received humane care and had an acclimatization period of at least 1 week in the central animal facility of the University of Bonn Medical Center under specific pathogen-free conditions according to the FELASA regulations (Federation of European Laboratory Animal Science Associations; www.felasa.org).

\section{Retrieval and Cold Storage of Small Bowel Grafts}

Prior to the surgical procedures, rats were fasted for $24 \mathrm{~h}$ while having free access to water, and then anesthetized by intramuscular injection of ketamine $(90 \mathrm{mg} / \mathrm{kg})$ and xylazine $(10 \mathrm{mg} / \mathrm{kg})$. The abdomen was opened by a midline incision with bilateral subcostal extensions, and the small bowel was isolated with the vascular pedicle, as described elsewhere [16]. The rats were administered heparin $(1,000 \mathrm{U} / \mathrm{kg})$ before organ retrieval. The superior mesenteric artery was cannulated with a 20-gauge polyethylene catheter and the jejunal segment was immediately flushed with $8 \mathrm{ml}$ of the respective solution (Polysol, Polysol + THP or lauryl-THP, each at $5 \mathrm{mg} / \mathrm{kg}$ body weight, the equivalent of 0.48 $\mathrm{mM}$ and $0.22 \mathrm{mM}$, respectively) at $4^{\circ} \mathrm{C}$. The portal vein was cannulated with a large polyethylene splint (ID $1.5 \mathrm{~mm}$ ), later connected to silicone tubing to allow the collection of the venous effluent upon reperfusion. A short 14-gauge cannula was inserted into the upper jejunal lumen and secured with a circumferential tie. The intestinal lumen was first flushed with $20 \mathrm{ml}$ cold normal saline solution to remove resident feces from the lumen, followed by a rinse with $15 \mathrm{ml}$ of the respective preservation solution (Poly- 
sol, Polysol + THP, or Polysol + lauryl-THP). Small bowel grafts (containing intraluminally the respective preservation solution) were stored ischemically for $18 \mathrm{~h}$ in a $50-\mathrm{ml}$ cold bath of Polysol (table 1), Polysol + THP or Polysol + lauryl-THP. The temperature was kept constantly at $4^{\circ} \mathrm{C}$ by an external cooling circuit (Ministat Digital Thermostat; Fa. Huber, Offenburg, Germany).

\section{Isolated Reperfusion}

Following ischemic cold storage, grafts were reperfused in vitro in a recirculating fashion at a constant flow rate of $8 \mathrm{ml} / \mathrm{min}$ for $30 \mathrm{~min}$, according to previously established techniques [16]. The grafts were weighed and then gently reflushed with $5 \mathrm{ml}$ of normal saline at $22^{\circ} \mathrm{C}$ via the superior mesenteric artery, to remove the organ preservation solution. They were then transferred into a temperature-controlled $\left(37^{\circ} \mathrm{C}\right)$ organ bath with modified Krebs-Henseleit buffer. The composition of the modified buffer was as follows: $5 \%$ dextran 78, 0.95\% Krebs-Henseleit buffer, 0.37 $\mathrm{g} / \mathrm{l}$ calcium chloride, $2 \mathrm{~g} / \mathrm{l}$ glucose, $0.6 \mathrm{~g} / \mathrm{l}$ dexamethasone, 70 $\mathrm{mg} / \mathrm{l}$ atropine and $0.21 \%$ sodium bicarbonate. Carbogen $\left(95 \% \mathrm{O}_{2}\right.$ $+5 \% \mathrm{CO}_{2}$ ) was used for oxygenation, and perfusate- $\mathrm{pO}_{2}$ was continuously kept over $500 \mathrm{~mm} \mathrm{Hg}$ during the whole reperfusion period. The effluent was intermittently collected through the portal vein for biochemical analysis. The intestinal lumen was simultaneously perfused by a perfusor (Braun, Melsungen, Germany) with normal saline solution $\left(37^{\circ} \mathrm{C}\right)$ containing $2 \mathrm{~g} / \mathrm{l}$ galactose at a constant flow rate of $0.5 \mathrm{ml} / \mathrm{min}$.

\section{Investigated Parameters}

At the end of reperfusion, tissue samples in all groups were snap frozen in liquid nitrogen and preserved below $-80^{\circ} \mathrm{C}$. To evaluate the extent of tissue damage, the following parameters were assessed in tissue samples and/or directly in the effluent reperfusion solution.

\section{Lactate Dehydrogenase Release}

Effluent activities of lactate dehydrogenase (LDH) were determined during and at the end of reperfusion in the portal effluent using a commercially available photometric kit (Roche, Mannheim, Germany) as an index for tissue damage of the grafts [16]. It is well known that LDH is a cytosolic enzyme that is released only when cell membrane integrity is damaged.

Nitrite Generation as a Measure of NO

Oxidation products $\left(\mathrm{NO}_{\mathrm{x}}^{-}\right)$of highly reactive $\mathrm{NO}$ were measured in the portal effluent after 30 min reperfusion, according to the Griess reaction as described in detail elsewhere [17]. Note that NO, a well-known physiological signaling and effector molecule in vivo, is also involved in the process of intestinal injury [18].

\section{Intestinal Carbohydrate Absorption}

Mucosal absorptive function was assessed by calculating the cumulative uptake of galactose, transferred from the intestinal lumen to the portal vein effluent during the first 15 min of reperfusion [19]. Effluent concentrations of galactose were measured in the collected perfusate with a galactose dehydrogenase commercially available test kit (Roche). Since galactose is presumed to share a common carrier system with glucose, its uptake from the intestinal lumen has been considered to be a useful parameter to estimate the preserved function of carbohydrate absorption after ischemic cold storage.
Table 1. Composition of Polysol

\begin{tabular}{ll}
\hline Component & Polysol \\
\hline Colloid & polyethylene glycol $(35 \mathrm{ku}), 20 \mathrm{~g} / \mathrm{l}$ \\
\hline $\mathrm{Na} / \mathrm{K}$ ratio & $135 / 5 \mathrm{mM}$ \\
\hline Buffers & histidine, $6.3 \mathrm{mM}^{\mathrm{H}_{2} \mathrm{PO}_{4}^{-}, 21.74 \mathrm{mM}}$ \\
& HEPES, $20 \mathrm{mM}^{\text {allopurinol, } 1.2 \mathrm{mM}}$ \\
\hline Antioxidants & glutathione, $3 \mathrm{mM}$ \\
& alpha-tocopherol, $5 \times 10^{-5} \mathrm{mM}$ \\
\hline ascorbic acid, $0.11 \mathrm{mM}$
\end{tabular}

a The following amino acids (in $\mathrm{mm}$ ) are supplemented in Polysol: alanine (1.01), arginine (1.18), asparagines (0.08), aspartic acid (0.23), cysteine $(0.33)$, cystine $(0.25)$, glutamic acid $(0.34)$, glutamine (0.002), glycine (0.67), isoleucine (0.38), leucine $(0.57)$, lysine (0.48), methionine (0.30), ornithine (2.00), phenylalanine $(0.30)$, proline $(0.78)$, serine $(0.29)$, threonine $(0.34)$, tryptophan (0.88), tyrosine (0.19) and valine (0.43).

$\mathrm{b}$ The following vitamins (in $\mathrm{mM}$ ) are supplemented in Polysol: ascorbic acid (0.011), biotin (0.021), Ca-pantothenate (0.004), choline chloride (0.01), inositol (0.07), ergocalciferol $\left(3 \times 10^{-4}\right)$, folic acid (0.002), menadione $\left(4 \times 10^{-5}\right)$, nicotinamide $(0.01)$, nicotinic acid (0.004), pyridoxal (0.005), riboflavin (0.003), thiamine (0.03), vitamin $\mathrm{A}\left(3 \times 10^{-4}\right)$, vitamin B12 $\left(1 \times 10^{-4}\right)$ and vitamin $\mathrm{E}\left(5 \times 10^{-5}\right)$.

\section{ATP Concentration}

Samples were first hammered (with a hammer and a sterile chisel) into small pieces under liquid nitrogen, weighed (wet weight) and freeze-dried in a high vacuum system at $-40^{\circ} \mathrm{C}$ for 6 days (Beta 5; Martin Christ Gefriertrocknungs-Anlagen $\mathrm{GmbH}$, Osterode, Germany). After complete removal of tissue water, the samples were weighed again (dry weight). The tissue concentrations of ATP 


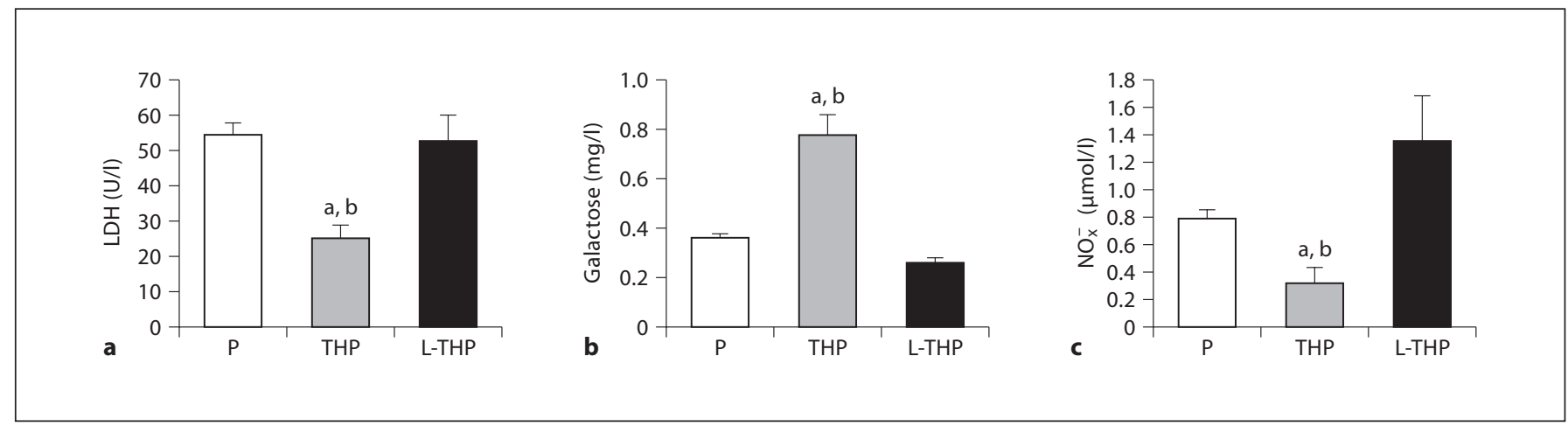

Fig. 2. Quantitative evaluation of released LDH activity (a), galactose resorption (b), and nitrite $\left(\mathrm{NO}_{\mathrm{x}}^{-}\right)$generation $(\mathbf{c})$ in the portal effluent. Small bowel grafts were harvested and stored under ischemic conditions for $18 \mathrm{~h}$ at $4{ }^{\circ} \mathrm{C}$ in the indicated storage solution as described in 'Materials and Methods'. Cumulative uptake of galactose was determined during the first $15 \mathrm{~min}$ of oxygenated reperfusion (being most stable during this time period), whereas the other 2 parameters were measured after $30 \mathrm{~min}$ of oxygenated reperfusion in the portal effluent as described in 'Materials and Methods'. $\mathrm{P}=$ Polysol group; THP = THP group; L-THP = laurylTHP group. Data are means \pm SEM, $\mathrm{n}=6$ within each group. ${ }^{\mathrm{a}} \mathrm{p}<0.05$ vs. Polysol; ${ }^{\mathrm{b}} \mathrm{p}<0.05$ vs. lauryl-THP. were determined by standard luminescence tests, according to the manufacturer's instructions, in a Tecan Safire2 multi-luminescence reader (Tecan Deutschland $\mathrm{GmbH}$, Crailsheim, Germany). The results were ultimately corrected with the respective wet weight per dry weight ratio of the samples and expressed in micromoles per gram of dry weight.

\section{Tissue Lipid Peroxidation}

Lipid peroxidation that occurred in the tissue was evaluated by measuring the amount of released malondialdehyde (MDA), a final product of lipid peroxidation [20,21]. Tissue MDA was extracted at $4^{\circ} \mathrm{C}$ in $10 \mathrm{ml} / \mathrm{g}$ dry weight (see above) of $0.33 \mathrm{~mol} / \mathrm{l}$ perchloric acid $\left(\mathrm{HClO}_{4}\right)$ and then neutralized with $2 \mathrm{~mol} / \mathrm{l}$ potassium hydroxide. After removing precipitated $\mathrm{KClO}_{4}$, the MDA concentrations were determined using a fluorometric method, as detailed elsewhere [22].

\section{Apoptosis}

Genomic DNA was directly analyzed as described previously [23]. Cell pellets or tissue samples were suspended in $500 \mu \mathrm{l}$ phosphate-buffered $\mathrm{NaCl}$ solution $\left(3 \mathrm{mM} \mathrm{KCl}, 1.5 \mathrm{mM} \mathrm{KH}_{2} \mathrm{PO}_{4}\right.$, $140 \mathrm{mM} \mathrm{NaCl}, 16 \mathrm{mM} \mathrm{Na}_{2} \mathrm{HPO}_{4}$, pH 7.4) and centrifuged again $\left(2,000 \mathrm{~g}, 10 \mathrm{~min}, 4^{\circ} \mathrm{C}\right)$. Genomic DNA was purified using QIAamp DNA Blood Mini Kit (Qiagen, Hilden, Germany) according to the protocol of the provider. Finally, $2 \mu \mathrm{g}$ of isolated DNA per sample were loaded onto a $2.0 \%$ agarose gel prepared from Agarose Low EEO (AppliChem, Darmstadt, Germany). After electrophoresis, DNA was visualized under UV light using ethidium bromide.

\section{Quantitative Evaluation of Ceramide}

Lipids were extracted in chloroform/methanol/water (10:5:1 $\mathrm{v} / \mathrm{v} / \mathrm{v})$ for $48 \mathrm{~h}$ at $48^{\circ} \mathrm{C}$. Lipid extracts were applied to thin layer Silica Gel 60 plates (Merck) as described previously [24]. Ceramides were resolved twice using chloroform/methanol/acetic acid $(190: 9: 1 \mathrm{v} / \mathrm{v} / \mathrm{v})$ as the developing system. After development, plates were air dried, sprayed with $8 \%(\mathrm{w} / \mathrm{v}) \mathrm{H}_{3} \mathrm{PO}_{4}$ containing $10 \%(\mathrm{w} / \mathrm{v})$ $\mathrm{CuSO}_{4}$, and charred at $180^{\circ} \mathrm{C}$ for $10 \mathrm{~min}$. Lipids were identified

Tissue-Protective Effect of

Tetrahydropyrimidine by their $\mathrm{R}_{\mathrm{f}}$ value using authentic lipid samples as references. Individual lipid bands obtained by thin layer chromatography were evaluated by photodensitometry (Shimadzu, Kyoto, Japan), using defined amounts of authentic ceramide as references.

\section{Electron Microscopy}

At the end of cold storage, additional tissue samples $(n=3$ each) were perfused with glutaraldehyde and paraformaldehyde solution ( $2 \%$ each in phosphate-buffered saline) through the superior mesenteric artery with a constant pressure of $70 \mathrm{~cm} \mathrm{H}_{2} \mathrm{O}$, then immersed into the same solution for at least 2 days at $4{ }^{\circ} \mathrm{C}$. The samples were cut into $0.5 \mathrm{~mm}$ slices, post-fixed with $\mathrm{OsO}_{4}$ (osmic acid fixative) and embedded in Epon 812 (Serva, Heidelberg, Germany). Semi-thin sections were then stained according to the procedure described by Richardson et al. [25]. Thin sections were thereafter stained with uranyl acetate and lead citrate, and then examined with a Phillips CM 10 electron microscope (Phillips, Eindhoven, The Netherlands).

\section{Statistical Analysis}

All results are expressed as means \pm SEM from at least 6 animals per group, unless otherwise stated. Comparisons between the 3 animal groups were performed by 1-way analysis of variance (ANOVA), followed by Tukey-Kramer's post-hoc test. The differences were considered statistically significant at $\mathrm{p}<0.05$.

\section{Results}

\section{THP but Not Lauryl-THP Considerably Improves}

\section{Tissue Quality after Exposure to I/R}

To evaluate the protective effect of THP in small bowel grafts subjected to cold ischemia and subsequent warm in vitro reperfusion, several parameters known to be indicative for tissue quality were evaluated either in the 
Fig. 3. Quantitative evaluation of ATP (a) and MDA (b) in intestinal tissue. Small bowel grafts were harvested and stored under ischemic conditions for $18 \mathrm{~h}$ at $4^{\circ} \mathrm{C}$ in the indicated storage solution as described in 'Materials and Methods'. After $30 \mathrm{~min}$ oxygenated reperfusion, the indicated parameters were determined in tissue samples as described in 'Materials and Methods'. $\mathrm{P}=$ Polysol group; THP = THP group; L-THP = lauryl-THP group. Data are means \pm SEM, $\mathrm{n}=6$ within each group. ${ }^{\mathrm{a}} \mathrm{p}<0.05$ vs. Polysol; ${ }^{\mathrm{b}} \mathrm{p}<0.05$ vs. lauryl-THP.

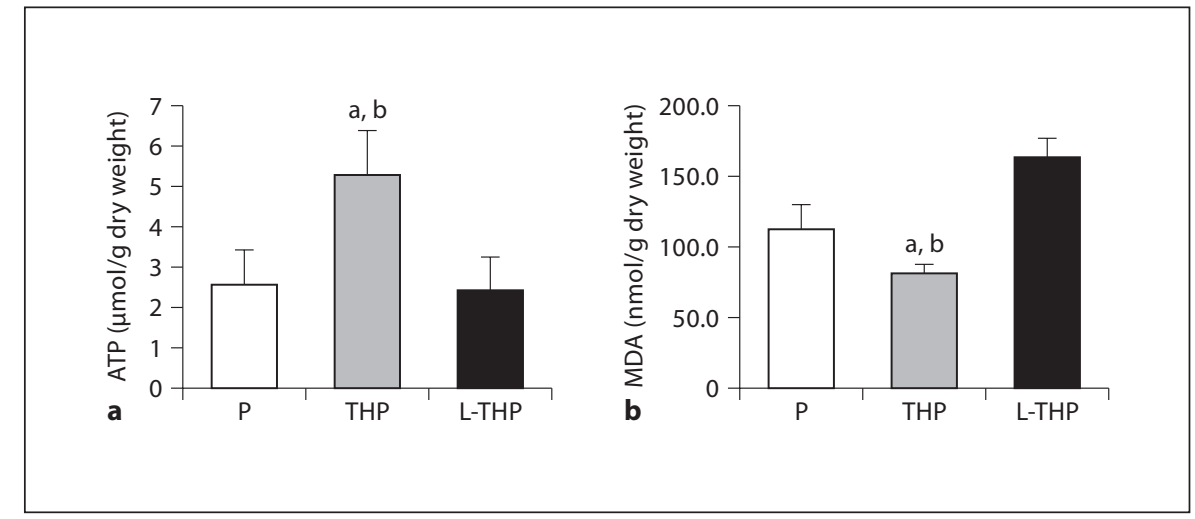

portal effluent or in the tissue samples. As shown in figure $2 \mathrm{a}, \mathrm{LDH}$ release determined after $18 \mathrm{~h}$ cold storage and subsequent oxygenated reperfusion was significantly reduced in the effluent of group THP. Thus, LDH activity released amounted to $47.4 \pm 4.9 \mathrm{U} / \mathrm{l}$ and $54.5 \pm 3.5$ $\mathrm{U} / \mathrm{l}$ after 15 and $30 \mathrm{~min}$, respectively, in group $\mathrm{P}$, whereas much lower amounts of LDH $(8.8 \pm 1.4 \mathrm{U} / \mathrm{l}$ after $15 \mathrm{~min}$ and $25.4 \pm 3.3 \mathrm{U} / \mathrm{l}$ after $30 \mathrm{~min}$ ) were measured in group THP. Interestingly, values measured in group L-THP were similar to those of group P (42 \pm 2 after $15 \mathrm{~min}$ and $53 \pm 7$ after $30 \mathrm{~min}$ ).

Accordingly, galactose uptake was 2-fold higher after 15 min of reperfusion in the portal effluent collected from group THP $(0.78 \pm 0.08 \mathrm{mg} / \mathrm{l})$ when compared to that collected from group $\mathrm{P}(0.36 \pm 0.02 \mathrm{mg} / \mathrm{l})$. Note that in group L-THP galactose uptake was even slightly lower than in group $P$, amounting to $0.26 \pm 0.02 \mathrm{mg} / \mathrm{l}$ (fig. $2 \mathrm{~b}$ ).

Furthermore, determination of $\mathrm{NO}_{\mathrm{x}}^{-}$in the effluent of the 3 groups after $30 \mathrm{~min}$ of reperfusion clearly argues for a protective effect of THP. As illustrated in figure 2c, THP considerably impeded $\mathrm{NO}_{\mathrm{x}}^{-}$and hence $\mathrm{NO}$ generation. Less than $50 \%$ of $\mathrm{NO}_{\mathrm{x}}^{-}$was detected after $30 \mathrm{~min}$ reperfusion in group THP $(0.325 \pm 0.105 \mu \mathrm{mol} / \mathrm{l})$ when compared with group $\mathrm{P}(0.787 \pm 0.063 \mu \mathrm{mol} / \mathrm{l})$, whereas considerably higher amounts were measured in group LTHP (fig. 2c).

Beside these parameters determined in the portal effluent, the amount of ATP was measured in tissue samples after $30 \mathrm{~min}$ of in vitro reperfusion. As shown in figure $3 \mathrm{a}$, the amount of ATP determined in tissue samples of group THP was about 2-fold higher than that of the 2 other groups. Note that the ATP content in the THP group amounted $80 \%$ of the ATP content of the fresh tissue control group that averaged $6.67 \pm 0.58 \mu \mathrm{mol} / \mathrm{g}$ dry weight.
A second parameter determined in tissue samples of the 3 groups was MDA, indicating the degree of lipid peroxidation in the tissue. As shown in figure $3 \mathrm{~b}$, the amount of MDA measured in tissue samples of group P amounted to $113 \pm 18 \mathrm{nmol} / \mathrm{g}$ dry weight and was significantly higher than that observed in group THP $(81 \pm 6 \mathrm{nmol} / \mathrm{g}$ dry weight), whereas group L-THP was even slightly higher than group $\mathrm{P}$, amounting to $165 \pm 13 \mathrm{nmol} / \mathrm{g}$ dry weight.

\section{THP Efficiently Reduces Morphological Tissue \\ Damage during $I / R$}

In addition to determination of biochemical parameters, electron microscopy studies were conducted to evaluate the graft tissue damage at the ultra-structural level, focusing on the formation of microvilli as well as on cell organelles in enterocytes. As illustrated in figure 4, significant differences regarding tissue morphology were visible in the presence or absence of THP during perfusion and ischemic cold storage of small bowel grafts. In group THP, epithelial microvilli of the luminal surface were much better preserved than in group P. Note the significantly reduced height of microvilli in the absence of THP. Cellular organelles including mitochondria and endoplasmic reticulum were also much better conserved in the presence of THP. The mitochondria in group $\mathrm{P}$ showed a lower electron density and cristae were hardly visible. By contrast, mitochondria in group THP kept their oval shape with well-maintained cristae formation. It is known that in contrast to the extreme vulnerability of the mucosal layer to ischemia and cold storage, the muscle layer is much more resistant. Indeed, no significant differences could be observed at the ultra-structural level between the 3 groups, when focusing on cell organelles in smooth muscle cells (re- 
Fig. 4. Ultra-structural analysis of intestinal mucosa after I/R. Small bowel grafts were harvested and stored under ischemic conditions for $18 \mathrm{~h}$ at $4^{\circ} \mathrm{C}$ in the indicated storage solution as described in 'Materials and Methods'. Tissue samples were fixed, cut, stained and examined by transmission electron microscopy as described in 'Materials and Methods'. Images are representative electron micrographs of the Polysol (P) and the THP (THP) group. Magnification $\times 10,500$. a, b Microvilli condition. $\mathbf{c}, \mathbf{d}$ Cell organelles. AM = Apical cell membrane; $\mathrm{ER}=$ endoplasmic reticulum; $\mathrm{M}=$ mitochondria; $\mathrm{MV}=$ microvilli.
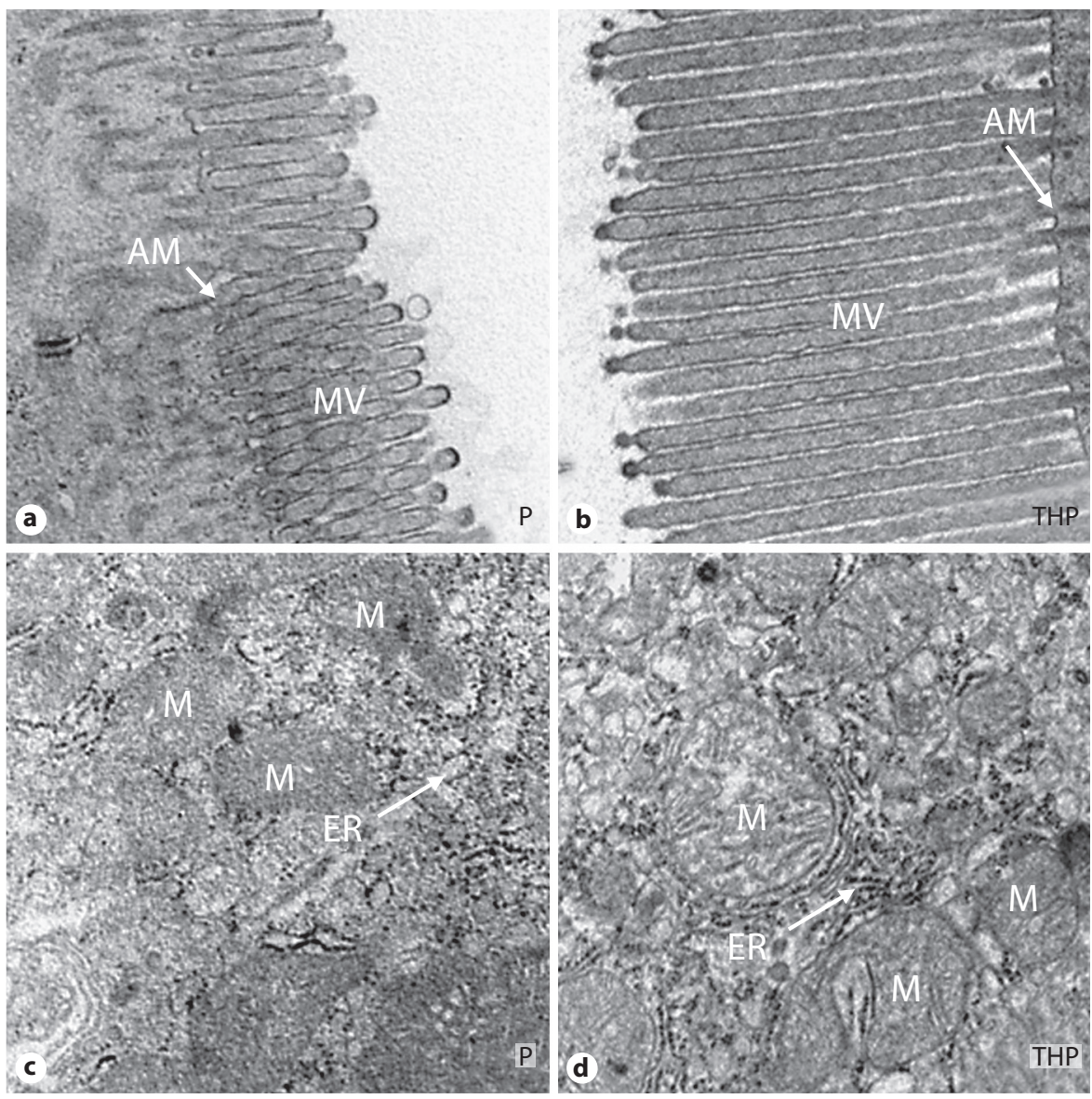

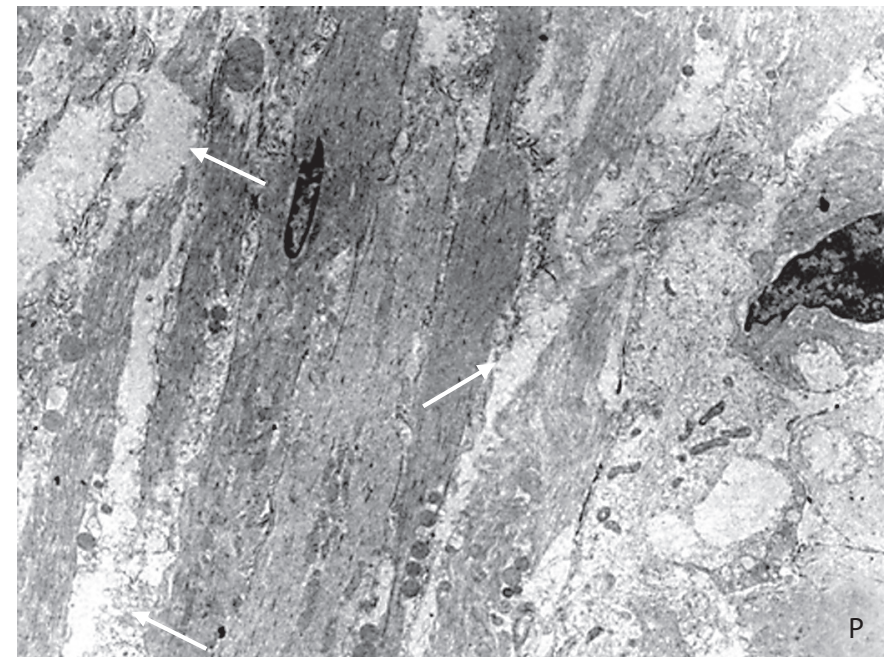

Fig. 5. Ultra-structural analysis of intestinal muscularis after I/R. Small bowel grafts were harvested and stored under ischemic conditions for $18 \mathrm{~h}$ at $4{ }^{\circ} \mathrm{C}$ in the indicated storage solution as described in 'Materials and Methods'. After 30 min oxygenated reperfusion, tissue samples were fixed, cut, stained and examined

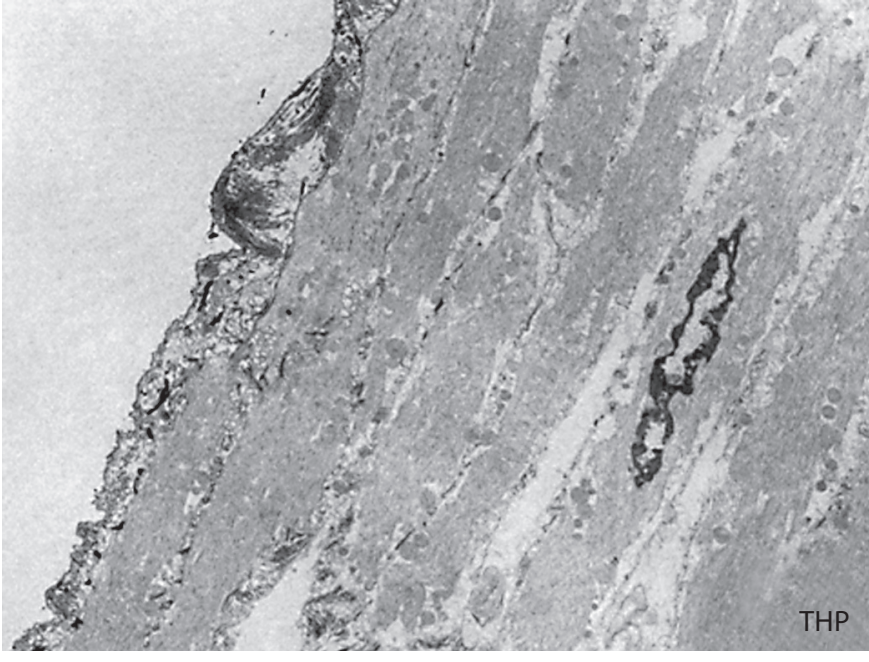

by transmission electron microscopy as described in 'Materials and Methods'. Images are representative electron micrographs of the Polysol (P) and the THP (THP) group. Magnification $\times 5,000$. Arrows point to enlarged intercellular spaces and edematous droplets. 

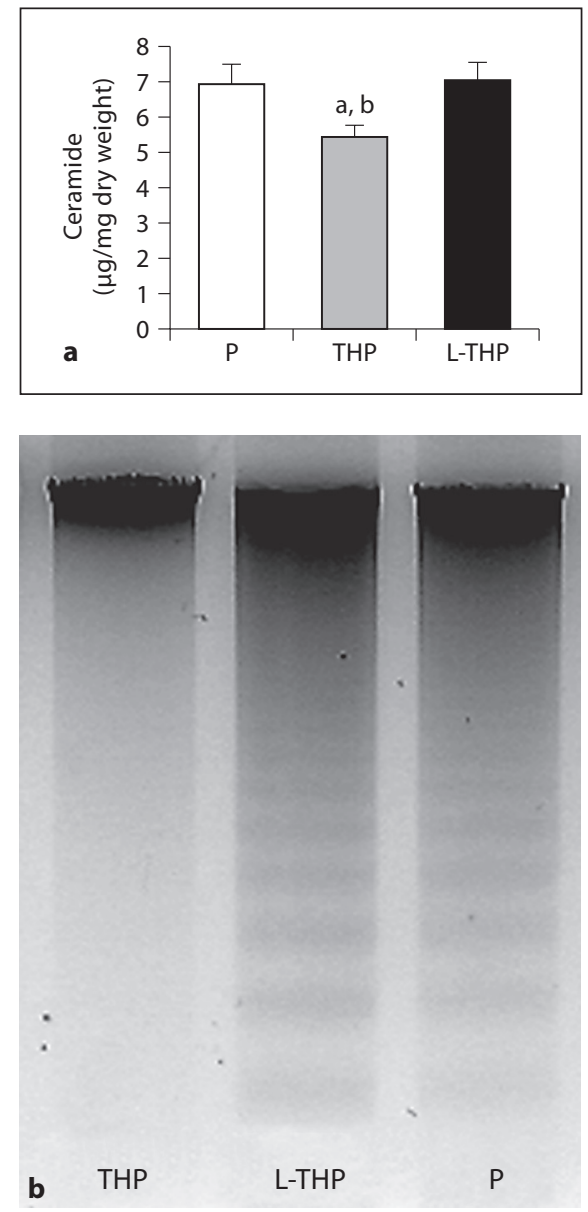

Fig. 6. Reduction of ceramide content by THP is accompanied by impediment of apoptosis in intestinal grafts. Small bowel grafts were harvested and stored under ischemic conditions for $18 \mathrm{~h}$ at $4{ }^{\circ} \mathrm{C}$ in the indicated storage solution as described in 'Materials and Methods'. After 30 min oxygenated reperfusion ceramide (a) was isolated and quantitatively evaluated or genomic DNA (b) was analyzed from tissue samples as described in 'Materials and Methods'. P = Polysol group; THP = THP group; L-THP = laurylTHP group. a Data are means $\pm \operatorname{SEM}(n=3)$. b Similar results were obtained from 2 animals per group. ${ }^{\mathrm{a}} \mathrm{p}<0.05$ vs. Polysol; ${ }^{\mathrm{b}} \mathrm{p}<0.05$ vs. lauryl-THP.

sult not shown). However, in intestinal muscularis of group P enlarged intercellular spaces with edematous, tumid structures could be observed, which were not found in group THP (fig. 5).

\section{THP Reduces Ceramide Content and Prevents \\ Apoptosis in vivo and in vitro}

The role of ceramide in yeast and mammalian stress responses has been discussed and experimentally documented for more than a decade [26-28]. In addition, cer- amide has emerged as an apoptotic trigger in several cells and tissues. As shown in figure 6, THP in contrast to lauryl-THP almost completely prevented I/R-induced apoptosis in intestinal grafts. To clarify whether this effect is correlated with ceramide levels, we determined the amount of ceramide in the small bowel following I/ $\mathrm{R}$ in the presence or absence of THP or its synthetic derivative. As illustrated in figure 6 , a significant reduction in ceramide content was observed only in group THP. The decrease in ceramide content correlated well with the extent of apoptosis in the intestinal tissue, as evaluated by DNA laddering (fig. 6). Note that lauryl-THP, which is unable to overcome tissue injury, did not affect either the content of ceramide or the apoptotic processes in intestinal tissue.

\section{Discussion}

It is generally accepted that I/R injury is the underlying pathophysiological mechanism for mucosal damage [29]. Although intestinal mucosa has high regenerative ability, Takeyoshi et al. [30] demonstrated that morphological recovery of the injured ileal mucosa after $24 \mathrm{~h}$ cold storage requires at least 1 month. This prolonged damage from I/R injury surely contributes not only to acute graft rejection, but also to various postoperative complications, such as bacterial translocation, endotoxin absorption and long-lasting malnutrition. Moreover, there have been lines of evidence demonstrating that the incidence of bacterial translocation was similar in allogenic and isogenic transplantation, even though no immunological rejections occurred in the latter [31, 32]. It has been suggested, in addition, that during organ harvesting and reperfusion an inflammatory response is initiated within the intestinal muscularis [33]. To overcome I/R-related tissue damage, we conducted a series of studies using different approaches. Polysol, a new preservation solution, which was originally developed for hypothermic machine perfusion of solid organs provided superior results in organ preservation including liver (as well as marginal livers), kidney and small bowel compared to the current clinical standard $[9,34,35]$. In the present study we demonstrate a further improvement of tissue quality following ischemic cold storage and in vitro reperfusion by the addition of THP to the storage solution. THP was selected based on previous studies indicating a potential tissue-protective property. Thus, apart from its wellknown protective properties for microorganisms, THP was shown to rescue proteins from misfolding or aggregation under non-physiological conditions [36, 37]. In 
addition, it was shown to protect zymogens from activation and to preserve proteolytic activity of trypsin and chymotrypsin during incubation [38]. As a result of these properties THP is often referred to as a small stress molecule or a small-molecule chaperone.

Note that all these studies on protective effects of THP were conducted in vitro and the concentration of THP applied was in the range of 100-800 mM. Cultured human dermal fibroblasts were the first mammalian cell model in which THP (1 mM) proved to counteract the effects of UVA-induced and accelerated skin aging [12]. In this study reduction of ceramide formation by THP was proposed to be essential for the protective effect. We found as well that ceramide content was decreased in the presence of THP, which improved mucosal barrier function as documented by 2 -fold lower amounts of released $\mathrm{LDH}$ on the one hand and a 2 -fold higher resorption of galactose on the other. By contrast, lauryl-THP failed to improve mucosal barrier function and, as expected, did not affect ceramide content either.

Similarly, THP in contrast to lauryl-THP improved mitochondrial structural and functional (ATP levels) integrity. It was shown before that apoptosis is the predominant form of cell death from intestinal I/R injury affecting permeability of intestinal mucosa [39]. Accordingly, along with an improved barrier function THP also prevented apoptosis, whereas lauryl-THP did not. It thus appears that membrane insertion expected only in case of laurylTHP does not improve but rather impairs the protective effect of THP. Furthermore, the anti-apoptotic effect of THP was paralleled by an impediment of ceramide increase. A growing number of reports document links between ceramide and mitochondria, especially in the context of regulation of apoptosis [40]. The role of mitochondria is well documented and generally accepted in apoptotic cell death [41] as well as in the generation of reactive oxygen species [42]. In the present study we found that parameters, which are indicative for oxidative stress including MDA and nitric oxide formation, were considerably reduced only in the THP group. Both parameters might be directly correlated with the structural integrity of mitochondria. Nitric oxide production is directly involved in post-ischemic intestinal injury, as reported recently [43], whereas lipid peroxidation is interconnected with membrane integrity [21]. Both parameters are thus essential for mucosal barrier function. Last but not least, reactive oxygen species were reported to activate a mitochondrial sphingomyelinase, thus generating a mitochondrial pool of ceramide, which was linked to mitochondrial cell death pathways [40]. Future studies will show whether the elevation of ceramide content in the absence of THP is due to a mitochondrial ceramide pool. Of interest, similar cytoprotective effects as those reported here were shown to be conferred by amino acids during small bowel preservation [44-47]. Based on structural similarity, one could also consider an analogous role of THP.

Taken together our data consistently demonstrate that cold storage of small bowel using Polysol plus THP resulted in an efficiently improved quality of graft preservation compared with Polysol alone. In addition, our results with lauryl-THP indicate that reduction of ceramide as a mediator of apoptosis and oxidative stress consistent with simultaneous mitochondrial damage might be essential for the protective effect of THP. The promising results of our study may promote THP as a valuable choice not only for small bowel, but also for organ and tissue preservation in general. However, future studies are needed to unravel the mechanism by which THP prevents increase of ceramide content in tissues and cells.

\section{Acknowledgments}

We thank Mareike Schulz and Joerg Bedorf for their skillful technical assistance.

This work was supported by Deutsche Forschungsgemeinschaft grants KFO 115: sub-project 7 (EC 118/1-3) and sub-project 10 (TO 542/1-1).

References

1 Intestinal Transplant Registry: 5 year patient survival (data up to 2003). Intestinal Transplant Registry, 2003.

2 Grant D, Wall W, Mimeault R, Zhong R, Ghent C, Garcia B, Stiller C, Duff J: Successful small-bowel/liver transplantation. Lancet 1990;335:181-184.

-3 Takara T, Guttman FM, Zorychta E, Lubin A, Mayer SK, Rosenmann E, Richardson J: Rat small bowel preservation for 24 and $48 \mathrm{~h}$. Transplant Proc 1993;25:2999-3000.

4 Granger DN, Benoit JN, Suzuki M, Grisham MB: Leukocyte adherence to venular endothelium during ischemia-reperfusion. Am J Physiol 1989;257:G683-G688.

5 Cecka JM: The UNOS Renal Transplant Registry. Clin Transpl 2002;1-20.

-6 Kokudo Y, Furuya T, Takeyoshi I, Nakamura K, Zhang S, Murase N, Todo S: Comparison of University of Wisconsin, Euro-Collins, and lactated Ringer's solutions in rat small bowel preservation for orthotopic small bowel transplantation. Transplant Proc 1994;26:1492-1493. 
7 Leuvenink HG, van Dijk A, Freund RL, Ploeg RJ, van Goor H: Luminal preservation of rat small intestine with University of Wisconsin or Celsior solution. Transplant Proc 2005;37: 445-447.

8 Middleton SJ, Jamieson NV: The current status of small bowel transplantation in the UK and internationally. Gut 2005;54:16501657.

9 Wei L, Hata K, Doorschodt BM, Buttner R, Minor T, Tolba RH: Experimental small bowel preservation using Polysol: a new alternative to University of Wisconsin solution, Celsior and histidine-tryptophan-ketoglutarate solution? World J Gastroenterol 2007;13:3684-3691.

10 Galinski EA: Osmoadaptation in bacteria. Adv Microb Physiol 1995;37:272-328.

11 Galinski EA, Pfeiffer HP, Truper HG: 1-, 4-, 5-, 6-Tetrahydro-2-methyl-4-pyrimidinecarboxylic acid. A novel cyclic amino acid from halophilic phototrophic bacteria of the genus Ectothiorhodospira. Eur J Biochem 1985;149:135-139.

$\checkmark 12$ Buenger J, Driller H: Ectoin: an effective natural substance to prevent UVA-induced premature photoaging. Skin Pharmacol Physiol 2004;17:232-237.

13 Wedeking A: Synthese von Ectoinderivaten und Untersuchungen zu deren Wirkung auf Säugerzellen. Diploma thesis, University of Bonn, 2005.

14 Hannun YA, Obeid LM: The ceramide-centric universe of lipid-mediated cell regulation: stress encounters of the lipid kind. J Biol Chem 2002;277:25847-25850.

-15 Dragusin M, Wehner S, Kelly S, Wang E, Merrill AH Jr, Kalff JC, van Echten-Deckert G: Effects of sphingosine-1-phosphate and ceramide-1-phosphate on rat intestinal smooth muscle cells: implications for postoperative ileus. FASEB J 2006;20:19301932.

-16 Minor T, Vollmar B, Menger MD, Isselhard $\mathrm{W}$ : Cold preservation of the small intestine with the new Celsior-solution. First experimental results. Transpl Int 1998;11:32-37.

17 Pinto PC, Lima JL, de Sousa Saraiva ML: Sequential injection analysis of nitrites and nitrates in human serum using nitrate reductase. Clin Chim Acta 2003;337:69-76.

$\checkmark 18$ Kubes P, McCafferty DM: Nitric oxide and intestinal inflammation. Am J Med 2000; 109:150-158.

19 Minor T, Klauke H, Isselhard W: Assessment of intestinal integrity after ischemic preservation by luminal and vascular perfusion in vitro. Eur Surg Res 1997;29:246-253.

-20 Casini AF, Ferrali M, Pompella A, Maellaro E, Comporti M: Lipid peroxidation and cellular damage in extrahepatic tissues of bromobenzene-intoxicated mice. Am J Pathol 1986;123:520-531.

- 21 Behn C, Araneda OF, Llanos AJ, Celedon G, Gonzalez G: Hypoxia-related lipid peroxidation: evidences, implications and approaches. Respir Physiol Neurobiol 2007;158:143-150.
22 Tolba RH, Akbar S, Muller A, Glatzel U, Minor T: Experimental liver preservation with Celsior: a novel alternative to University of Wisconsin and histidine-tryptophan-alphaketoglutarate solutions? Eur Surg Res 2000; 32:142-147.

23 Natzker S, Heinemann T, Figueroa-Perez S, Schnieders B, Schmidt RR, Sandhoff K, van Echten-Deckert G: Cis-4-methylsphingosine phosphate induces apoptosis in neuroblastoma cells by opposite effects on p38 and ERK mitogen-activated protein kinases. Biol Chem 2002;383:1885-1894.

24 van Echten-Deckert G: Sphingolipid extraction and analysis by thin-layer chromatography. Methods Enzymol 2000;312:64-79.

25 Richardson KC, Jarett L, Finke EH: Embedding in epoxy resins for ultrathin sectioning in electron microscopy. Stain Technol 1960; 35:313-323.

26 Obeid LM, Hannun YA: Ceramide: a stress signal and mediator of growth suppression and apoptosis. J Cell Biochem 1995;58:191198.

27 Hannun YA, Obeid LM: Ceramide and the eukaryotic stress response. Biochem Soc Trans 1997;25:1171-1175.

28 Gulbins E, Kolesnick R: Raft ceramide in molecular medicine. Oncogene 2003;22: 7070-7077.

29 Kong SE, Blennerhassett LR, Heel KA, McCauley RD, Hall JC: Ischaemia-reperfusion injury to the intestine. Aust NZ J Surg 1998; 68:554-561.

30 Takeyoshi I, Zhang S, Nomoto M, Zhu Y, Kokudo Y, Suzuki T, Hamada N, Nemoto A, Starzl TE, Todo S: Mucosal damage and recovery of the intestine after prolonged preservation and transplantation in dogs. Transplantation 2001;71:1-7.

31 Biffi R, Privitera G, Andreoni B, Matinato C, Pozzi S, Marzona L, Danza M, Rai P, Tiberio G: Luminal bacterial overgrowth and intestinal translocation in pigs given either cyclosporin A or 15-deoxyspergualin after small bowel transplantation. Eur J Surg 1995;161: 93-96.

32 Zou Y, Hernandez F, Burgos E, Martinez L, Gonzalez-Reyes S, Fernandez-Dumont V, Lopez G, Romero M, Lopez-Santamaria M, Tovar JA: Bacterial translocation in acute rejection after small bowel transplantation in rats. Pediatr Surg Int 2005;21:208-211.

-33 Turler A, Kalff JC, Heeckt P, Abu-Elmagd $\mathrm{KM}$, Schraut WH, Bond GJ, Moore BA, Brunagel G, Bauer AJ: Molecular and functional observations on the donor intestinal muscularis during human small bowel transplantation. Gastroenterology 2002; 122: 1886-1897.

34 Bessems M, Doorschodt BM, Albers PS, van Vliet AK, van Gulik TM: Wash-out of the non-heart-beating donor liver: a comparison between ringer lactate, HTK, and polysol. Transplant Proc 2005;37:395-398.
35 Hata K, Tolba RH, Wei L, Doorschodt BM, Buttner R, Yamamoto Y, Minor T: Impact of polysol, a newly developed preservation solution, on cold storage of steatotic rat livers. Liver Transpl 2007;13:114-121.

36 Arora A, Ha C, Park CB: Inhibition of insulin amyloid formation by small stress molecules. FEBS Lett 2004;564:121-125.

37 Kanapathipillai M, Lentzen G, Sierks M, Park CB: Ectoine and hydroxyectoine inhibit aggregation and neurotoxicity of Alzheimer's beta-amyloid. FEBS Lett 2005;579: 4775-4780.

- 38 Kolp S, Pietsch M, Galinski EA, Gutschow M: Compatible solutes as protectants for zymogens against proteolysis. Biochim Biophys Acta 2006;1764:1234-1242.

-39 Ikeda H, Suzuki Y, Suzuki M, Koike M, Tamura J, Tong J, Nomura M, Itoh G: Apoptosis is a major mode of cell death caused by ischaemia and ischaemia/reperfusion injury to the rat intestinal epithelium. Gut 1998;42: 530-537.

40 Birbes H, El Bawab S, Obeid LM, Hannun YA: Mitochondria and ceramide: intertwined roles in regulation of apoptosis. Adv Enzyme Regul 2002;42:113-129.

41 Kaufmann SH, Hengartner MO: Programmed cell death: alive and well in the new millennium. Trends Cell Biol 2001;11: 526-534.

42 Schulze-Osthoff K, Bakker AC, Vanhaesebroeck B, Beyaert R, Jacob WA, Fiers W: Cytotoxic activity of tumor necrosis factor is mediated by early damage of mitochondrial functions. Evidence for the involvement of mitochondrial radical generation. J Biol Chem 1992;267:5317-5323.

43 Naito Y, Takagi T, Ichikawa H, Tomatsuri N, Kuroda M, Isozaki Y, Katada K, Uchiyama K, Kokura S, Yoshida N, Okanoue T, Yoshikawa $\mathrm{T}$ : A novel potent inhibitor of inducible nitric oxide inhibitor, ONO-1714, reduces intestinal ischemia-reperfusion injury in rats. $\mathrm{Ni}$ tric Oxide 2004;10:170-177.

44 Salehi P, Zhu JZ, Castillo EG, Avila J, Lakey J, Churchill TA: Preserving the mucosal barrier during small bowel storage. Transplantation 2003;76:911-917.

45 Olson DW, Jijon H, Madsen KL, Al-Saghier M, Zeng J, Jewell LD, Bigam DL, Churchill TA: Human small bowel storage: the role for luminal preservation solutions. Transplantation 2003;76:709-714.

-46 Fujimoto Y, Olson DW, Madsen KL, Zeng J, Jewell LD, Kneteman NM, Bigam DL, Churchill TA: Defining the role of a tailored luminal solution for small bowel preservation. Am J Transplant 2002;2:229-236.

-47 Salehi P, Bigam DL, Ewaschuk JB, Madsen KL, Sigurdson GT, Jewell LD, Churchill TA: Alleviating intestinal ischemia-reperfusion injury in an in vivo large animal model: developing an organ-specific preservation solution. Transplantation 2008;85:878-884. 